\title{
ENTEROPATHOGENS DETECTED IN A DAYCARE CENTER, SOUTHEASTERN BRAZIL: BACTERIA, VIRUS, AND PARASITE RESEARCH
}

\author{
Edna Donizetti Rossi CASTRO(1)*, Marcela Cristina Braga Yassaka GERMINI(1)*, Joana D'Arc Pereira MASCARENHAS(2), \\ Yvone Benchimol GABBAY(2), Ian Carlos Gomes de LIMA(2), Patrícia dos Santos LOBO(2), Valéria Daltibari FRAGA(1), \\ Luciana Moran CONCEIÇÃO(1), Ricardo Luiz Dantas MACHADO(1,3) \& Andréa Regina Baptista ROSSIT $(1,4)$
}

\begin{abstract}
SUMMARY
Introduction: The objective of this study was to determine the prevalence and etiological profile of enteropathogens in children from a daycare center. Methods: From October 2010 to February 2011 stool samples from 100 children enrolled in a government daycare center in the municipality of São José do Rio Preto, in the state of São Paulo, were collected and analyzed. Results: A total of 246 bacteria were isolated in $99 \%$ of the fecal samples; 129 were in the diarrheal group and 117 in the non-diarrheal group. Seventythree strains of Escherichia coli were isolated, 19 of Enterobacter, one of Alcaligenes and one of Proteus. There were 14 cases of mixed colonization with Enterobacter and E. coli. Norovirus and Astrovirus were detected in children with clinical signs suggestive of diarrhea. These viruses were detected exclusively among children residing in urban areas. All fecal samples were negative for the presence of the rotavirus species A and C. The presence of Giardia lamblia, Entamoeba coli, Endolimax nana and hookworm was observed. A significant association was found between food consumption outside home and daycare center and the presence of intestinal parasites. Conclusions: For children of this daycare center, intestinal infection due to pathogens does not seem to have contributed to the occurrence of diarrhea or other intestinal symptoms. The observed differences may be due to the wide diversity of geographical, social and economic characteristics and the climate of Brazil, all of which have been reported as critical factors in the modulation of the frequency of different enteropathogens.
\end{abstract}

KEYWORDS: Childhood diarrhea; Gastroenteritis; Daycare center; Enteropathogens.

\section{INTRODUCTION}

In 2009, the World Health Organization (WHO) estimated that approximately nine million under 5-year-old children die each year. Diarrhea is reported to be the second most important disease in the etiology of infant death ${ }^{33}$. In developing countries, gastrointestinal disorders are directly associated with higher infant morbidity and mortality in this age group, resulting in 2.5 million deaths per year ${ }^{28}$.

Infectious diarrhea is generally caused by bacterial, viral and parasitic pathogens whose actions may result in malabsorption of water, electrolytes and nutrients ${ }^{30}$. Intestinal infections are closely correlated to young age, immune status, nutritional deficiencies, inadequate food hygiene practices, early weaning, level of schooling of guardians/ caregivers, gatherings at home and in institutions such as daycare centers and schools, lack of basic sanitation, access to treated water and the high temperatures during the year ${ }^{23}$.

Recently, profound changes in some urban centers' workforce have been reported in Brazil, and as a result, a large number of children are being cared for outside the familial environment in daycare centers ${ }^{29}$. Due to the greater urbanization and the effective participation of women in the economically active working force, these institutions have become the main place frequented by children outside their home environment and as such, a potential environment for contamination ${ }^{36}$.

Although infectious enteric diseases are more evident in children with severe infections that culminate in hospitalization, a large number of infections are endemic in the community, presenting as asymptomatic or with mild clinical symptoms. This is particularly true for parasites, as the progression is often slower ${ }^{30}$. In Brazil few official data about the in depth prevalence of infectious intestinal diseases in children are available, especially those including the infectious agents implicated in the etiology of these diseases in different regions of the country ${ }^{3}$. Nevertheless, such knowledge is essential for the development of effective prevention strategies.

The objective of the current study was to determine the prevalence of these infections and the etiology of diarrhea in the infant population of a daycare center situated in an urban area of disadvantaged socioeconomic conditions.

*The authors contributed equally to this work.

(1) Microorganisms Research Centre, Sao Jose do Rio Preto Faculty of Medicine, Sao Paulo, Brazil.

(2) Virology Section, Evandro Chagas Institute, Ananindeua, Pará, Brazil.

(3) Parasitology Section, Evandro Chagas Institute, Ananindeua, Pará, Brazil.

(4) Department of Microbiology and Parasitology, Biomedical Institute of the Fluminense Federal University, Niterói, Rio de Janeiro, Brazil.

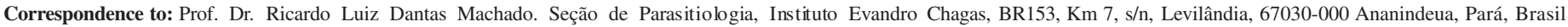
Phone: +55.91.32142089. E-mail: ricardomachado@iec.pa.gov.br 


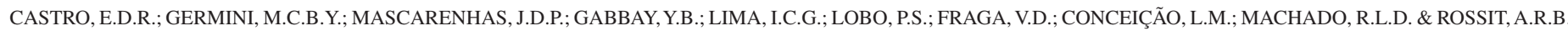
- Enteropathogens detected in a daycare center, Southeastern Brazil: bacteria, virus, and parasite research. Rev. Inst. Med. Trop. Sao Paulo, 57(1): 27-32, 2015.

\section{MATERIAL AND METHODS}

Study region and participants: In the period from October 2010 to February 2011, stool samples of 100 children were tested in a government daycare center in São José do Rio Preto (latitude 20'89'72' S and longitude $49^{\circ} 37^{\prime} 44^{\prime \prime} \mathrm{W}$ at an altitude of $489 \mathrm{~m}$ above sea level) located in the Northwest São Paulo State region, $450 \mathrm{~km}$ from the city of São Paulo. The population of this city is 419,632 with an area of $431 \mathrm{~km}^{2}$. Participants were allocated in two groups: Diarrheal Group - defined by the occurrence of three or more liquid or semi- liquid evacuations in the 24 hours before fecal collection and Non-diarrheal Group - comprised of children from the same daycare center paired by age and gender. Fecal samples were collected in clean flasks and then sent immediately to the Microorganisms Research Centre of FAMERP for parasitological and microbiological analysis. A standard questionnaire was applied to assess the children's socioeconomic conditions including information on age, gender, family structure, hygiene and water consumption source and treatment in their homes. Structural characteristics of the daycare center were also obtained.

The project was approved by the Research Ethics Committee of FAMERP (Protocol CEP 6332/209) and written informed consent was provided by parents or guardians after a detailed explanation of the objectives of the work.

Laboratorial analysis: Stool samples were evaluated using Cary-Blair transport medium for bacterial analysis. A second clean flask was used to collect stools to investigate parasites and viruses.

Enterobacteria: All samples were analyzed on the day of collection. Briefly, colonies were isolated using McConkey agar, ShigellaSalmonella agar, brilliant green (after enrichment in tetrathionate broth) and Columbia Agar to isolate and identify the following bacteria: enteropathogenic Escherichia coli (EPEC), enterohemorrhagic E. coli (EHEC), enteroinvasive E. coli (EIEC), enterotoxigenic E. coli (ETEC), Shigella spp., Salmonella spp., Yersinia spp. and Campylobacter jejuni. Isolates identified by biochemical tests (EPM-Milli and Oxidase stripes) were serotyped by standard techniques in addition to commercially available antisera (Probac, Brazil).

Parasites: For each patient, a fecal sample was collected in a universal sterile container with no preservative solution and maintained at $4{ }^{\circ} \mathrm{C}$ until laboratory analysis on the same day. Flasks were labeled with the name of the patient and data on collection. The Hoffman-Pons-Janer ${ }^{24}$, centrifugal flotation in zinc sulfate solution ${ }^{13}$ and Baermann-Moraes methods were used to prepare samples. Two slides were examined for each stool sample to detect parasites using optical microscopy (Nikon, Japan) with magnifications of $100 \times$ and $400 \times$, by two researchers.

Enteric viruses: The detection of rotavirus, norovirus and astrovirus was performed by molecular methods using the same fecal suspension used in the investigation of parasites, which was diluted in water and kept at a low temperature until the test. In brief, viral RNA was extracted as described by BOOM et al. with modifications ${ }^{4,6}$. Reverse transcription (RT) was performed to obtain complementary DNA using a random primer [hexamer pd(N)6-50 A260 units; Amersham Biosciences, Freiburg, Germany]. For norovirus detection the polymerase chain reaction (PCR) was used with the pool of primers Mon 432/434 and
Mon 431/433 partial region of the RNA- dependent RNA polymerase -RdRp) that detects the NoVs genogroups I and II, respectively ${ }^{35}$. The human astrovirus (HAstV) study was performed using the PCR and primers Mon 269 and Mon 270 (ORF2 region) ${ }^{35}$. PCR products were subjected to $1 \%$ agarose gel electrophoresis using SYBR Safe DNA Gel Stain (Invitrogen, Eugene, Oregon, USA). Photodocumentation was performed using the Gel Doc 1000 imaging system (BioRad, Hercules, CA). Samples with an amplicon of 213 and 449 base pairs (bp) were considered positive for norovirus and astrovirus respectively.

The RNA obtained in the fecal specimens was tested for rotavirus species A and C using polyacrylamide gel electrophoresis as described by PEREIRA et al. ${ }^{38}$. RT- PCR was employed to detect rotavirus species C as described by GOUVEA et al. ${ }^{21}$ and KAZUYA et $a l .{ }^{25}$ for the VP6 and VP7 genes, respectively. Products were stained using SyBR ${ }^{\circledR}$ safe DNA Gel Stain (Invitrogen TM, Eugene, Oregon, USA) in the loading buffer, run in $1.5 \%$ agarose gel and documented in a Doc Gel 1000 imaging system (BioRad, Hercules, CA). Samples that presented fragments of $356 \mathrm{bp}$ and $1027 \mathrm{pb}$ were considered positive, for the VP6 and VP7 genes, respectively.

Statistical analysis: Statistical analysis was performed using the Epi-Info statistics program (version 6.0). The v2 test or the Fisher exact test was applied to obtain independence between proportions. The relationship between the clinical characteristics of the participants and the presence of enteropathogens was assessed using the Wilcoxon Rank Sum test. The level of significance adopted for statistical inference was $5 \%$.

\section{RESULTS}

Of the 100 fecal samples tested, 50 were in the Diarrheal Group and 50 in the Non-diarrheal Group. There were no differences between the two groups regarding gender. As summarized in Table 1, most individuals lived in treated water and sanitary sewer system available houses. No significant association was observed between these variables and the presence of enteropathogens (data not shown) or diarrhea, except for food consumption outside home or the daycare center and the presence of intestinal parasites (Chi-square; $p$-value $=0.0053$ ).

A total of 246 bacteria were isolated in $99 \%$ of all fecal samples; 129 were in the Diarrheal Group and 117 in the Non-diarrheal Group. Of this total, 44 children had at least one species of bacterium, 37 children had two, while 17 children had three. Four distinct bacteria were isolated in the fecal material of one of the children. Seventy-three strains of Escherichia coli were isolated ( $73.7 \%$ of the E. coli $\mathrm{O} 157$ strain), 19 Enterobacter (19.1\%), one Alcaligenes (1.0\%) and one Proteus (1.0\%). There were 14 cases of mixed colonization with Enterobacter and E. coli (14.1\%).

Noroviruses (2\%) and Astrovirus (1\%) were detected in children with clinical signs suggestive of diarrhea (Table 2). These viruses were detected exclusively among children residing in urban areas ( $p$-value $<0.0001)$. All fecal samples were negative for the presence of the rotavirus species $\mathrm{A}$ and $\mathrm{C}$.

Parasites were detected in 49 of the fecal samples evaluated, as shown in Table 2. The prevalence of at least one parasite in the entire study population was $42.0 \%$. There were seven cases of parasitism involving two organisms: five were associations between $G$. lamblia and E. coli 


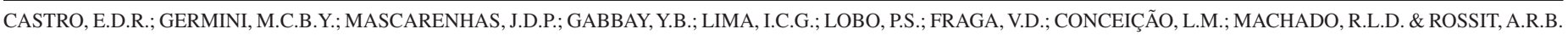
- Enteropathogens detected in a daycare center, Southeastern Brazil: bacteria, virus, and parasite research. Rev. Inst. Med. Trop. Sao Paulo, 57(1): 27-32, 2015.

Table 1

Social indicators, hygiene, water source and food consumption habits of 100 children of a government daycare center in the city of São José do Rio Preto, São Paulo grouped as Diarrheal $(n=50)$ or Non-diarrheal $(n=50)$

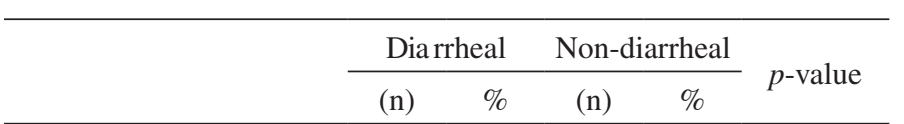

Gender

$\begin{array}{lllll}\text { Female } & 25 & 50.0 & 27 & 54.0 \\ \text { Male } & 25 & 50.0 & 23 & 46.0\end{array}$

Treated drinking water

$\begin{array}{lllll}\text { Yes } & 2 & 4.0 & 8 & 16.0\end{array}$

Source of water

Public reservoir

$\begin{array}{llll}44 & 88.0 \quad 44 & 88.0\end{array}$

Pets at home

$\begin{array}{lllll}\text { Yes } & 22 & 44.0 & 25 & 50.0\end{array}$

Sewer system at ho me

$\begin{array}{lllll}\text { Yes } & 50 & 100.0 & 48 & 96.0\end{array}$

Ingestion of raw food

Yes

$\begin{array}{llll}35 & 70.0 & 30 & 60.0\end{array}$

Meals outside the residence or daycare center

\begin{tabular}{llllll} 
Yes & 23 & 46.0 & 09 & 18.0 & $0.0053^{*}$ \\
\hline
\end{tabular}

*Chi-square test.

(5.0\%), one of G. lamblia and E. nana (1.0\%) and the other between $G$. lamblia and hookworm (1.0\%).

Table 3 shows no statistically significant differences after stratified analysis of the samples divided into Diarrheal and Non-diarrheal Groups versus clinical signs suggestive of diarrhea or versus the presence of enteropathogens (data not shown).

\section{DISCUSSION}

This study was carried out during a period without any registers of diarrhea outbreak. Despite the presence of EPEC, EIEC, E. coli O157 and Pseudomonas spp., no association was observed between bacteria and diarrhea clinical symptoms. Similar results were observed in a case-control study conducted in a HIV-1 positive infant ${ }^{40}$ population as well as in a HIV1 seropositive adult population ${ }^{20}$, both from the same region. However, in another investigation conducted in the 1990s, diarrhea was associated with these enterobacteria in a population treated in the Pediatrics Outpatient Clinic of a Hospital in São José do Rio Preto, Sao Paulo². This implies that strains of bacteria with different virulence circulate in the population of this region and, therefore, they may pose a risk of diarrhea. Intestinal infections caused by EIEC are rare but are more common in children over two, as observed in the current study, and also in adults ${ }^{20}$.

Noroviruses were detected in $2 \%$ of the Diarrheal group. In a retrospective study, conducted in a daycare center in Rio de Janeiro
Table 2

Detection of bacterias, virus and parasites in fecal specimens from a daycare center located in São José do Rio Preto, São Paulo. October 2010 to February 2011

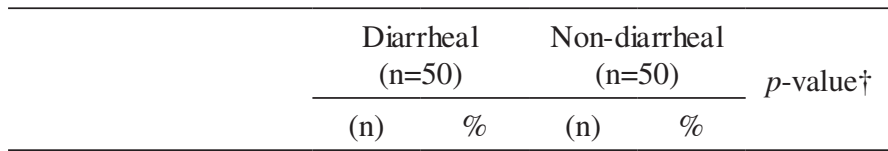

Bacteria

$\begin{array}{lccccc}\text { Acinetobacter } & - & 0.0 & 1 & 2.0 & 1.0000 \\ \text { EPEC } & 12 & 24.0 & 8 & 16.0 & 0.4533 \\ \text { EIEC } & 3 & 6.0 & 1 & 2.0 & 0.6098 \\ \text { E. coli O157 } & 1 & 2.0 & 2 & 4.0 & 1.0000 \\ \text { Pseudomonas } & 2 & 4.0 & 4 & 8.0 & 0.6737\end{array}$

Viruses

$\begin{array}{llllll}\text { Norovirus } & 2 & 4.0 & 0 & 0.0 & 0.4751 \\ \text { Astrovirus } & 1 & 2.0 & 0 & 0.0 & 1.0000 \\ \text { Rotavirus A } & 0 & 0.0 & 0 & 0.0 & 0.7025 \\ \text { Rotavirus C } & 0 & 0.0 & 0 & 0.0 & 0.7025\end{array}$

Parasites

$\begin{array}{lccccc}\text { Giardia lamblia } & 20 & 40.0 & 24 & 48.0 & 0.5456 \\ \text { Entamoeba coli } & 1 & 2.0 & 6 & 12.0 & 0.1169 \\ \text { Endolimax nana } & 3 & 6.0 & 1 & 2.0 & 0.6098 \\ \text { Hookworm } & 1 & 2.0 & 0 & 0.0 & 1.0000\end{array}$

EPEC: enteropathogenic Escherichia coli; EIEC: enteroinvasive E. coli; $\uparrow$ : Fisher exact test.

Table 3

Clinical data obtained of children in a government daycare center of São José do Rio Preto, São Paulo State, grouped according to clinical signs suggestive of diarrhea in Diarrheal and Non-diarrheal Groups

\begin{tabular}{lcccc}
\hline & \multicolumn{2}{c}{ Diarrheal $(\mathrm{n}=50)$} & \multicolumn{2}{c}{ Non-diarrheal $(\mathrm{n}=50)$} \\
\cline { 2 - 5 } & $(\mathrm{n})$ & $\%$ & $(\mathrm{n})$ & $\%$ \\
\hline Fever & & & & \\
$\quad$ Yes & 14 & 28.0 & 13 & 26.0 \\
$\quad$ No & 34 & 68.0 & 37 & 74.0 \\
Blood in the feces & & & & \\
$\quad$ Yes & 0 & 0.0 & 1 & 2.0 \\
$\quad$ No & 49 & 98.0 & 49 & 98.0 \\
Abdominal pain & & & & \\
$\quad$ Yes & 11 & 22.0 & 4 & 8.0 \\
$\quad$ No & 38 & 76.0 & 46 & 92.0 \\
Vomits & & & & \\
$\quad$ Yes & 8 & 16.0 & 5 & 10.0 \\
$\quad$ No & 42 & 84.0 & 45 & 90.0 \\
\hline
\end{tabular}




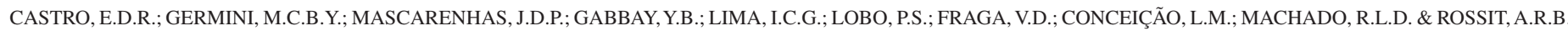
- Enteropathogens detected in a daycare center, Southeastern Brazil: bacteria, virus, and parasite research. Rev. Inst. Med. Trop. Sao Paulo, 57(1): 27-32, 2015.

involving children under five, with acute gastroenteritis, the occurrence of noroviruses was higher ranging from 23 to $67 \%$. Furthermore, norovirus (GII) was responsible for three out of four of the studied outbreaks ${ }^{18}$. In Brazil, the HAstV caused 3 to $11 \%$ of the cases of acute gastroenteritis in children under $5^{6,16}$. The prevalence of HAstV obtained in this study $(1 \%)$ is lower than that reported by other authors $(2-5 \%)^{42}$ and quite different to the prevalences described in other developing countries (2-26\%) or even in developed countries $(2-11 \%)^{9-11}$. Rotavirus species $\mathrm{A}$ and $\mathrm{C}$ were not detected in the population of the daycare center here evaluated. This may be explained by the high vaccination coverage in São José do Rio Preto (99\%), which provides protection against the most common rotavirus, species $\mathrm{A}^{37}$. Indeed, studies in several countries have shown that rotavirus species $\mathrm{C}$ is not as uncommon as thought, however its prevalence is low $(0.4-35 \%)^{15,17,26,34}$.

Despite the absence of any association with diarrhea, these viruses were detected in the studied population. It should be noted that the transmission of norovirus is very efficient, with rapid dispersal during outbreaks, primarily due to the high infectivity of this agent when an inoculum of only 10 to 100 virions is enough to cause an infection. Furthermore, it is of concern that infected people can transmit the virus after recovering from the symptoms as they continue to eliminate viral particles for up to three weeks ${ }^{39,41}$. Contamination of drinking water and water used for recreational activities can serve as a primary source of outbreak as noroviruses are resistant to treatment with chlorine and may remain infectious for long periods in this environment ${ }^{37}$.

In daycare centers of different Brazilian cities, there is a wide variation in the prevalence of intestinal parasitic diseases, ranging from $15.2 \%{ }^{19}$ to $53.4 \%{ }^{29}$. This is in accordance with the $49.0 \%$ verified in this study, where approximately 14 children have parasitism involving infection by two parasites. The different enteric parasite incidences observed in this study may be due to the wide diversity of geographical, social, economic characteristics and climate in Brazil, which are reported as critical factors in the modulation of the frequency of different enteric parasites ${ }^{40}$. Although most children received treated water, a higher prevalence of water-borne parasites was found. These results suggest that the use of treated water is not a protective factor against water-borne parasites or that water treatment does not follow the ideal procedures to eliminate parasites.

The prevalence of giardiasis in Brazil ${ }^{7,22}$ and in the state of São Paulo $^{8,29}$ varies, on average, between $4 \%$ and $30 \%$, with variation also reported in daycare centers. The highest frequency for this protozoan was associated with the 1- to 2-year age range followed by the over 3 -year-old population, which is probably related to the high rate of fecal-oral transmission of the pathogen ${ }^{1}$. Due to the common detection of G. lamblia cysts on fingers and under nails, it is possible that caregivers in daycare centers are the main form of transmission of this parasite among children.

This study identified low prevalence of Entamoeba coli (2.0\%) and Endolimax nana $(2.0 \%)$ demonstrating that these amoebae may not be endemic in the region. However, it should be pointed out that the detection of commensal amoebas may indicate that the children ingested water or food contaminated with fecal waste and that they are therefore at risk for contamination by Entamoeba histolytica, which has a high prevalence in tropical regions ${ }^{32}$.
In this study, just one case of hookworms associated with G. lamblia was identified in a non-diarrheal one-year-old child. This is actually one of the most common helminths transmitted worldwide; higher rates have been reported in daycare centers in Northeastern Brazil ${ }^{23,31}$. Furthermore, the majority of children included in this study have piped water and a sewer system in their homes. There is a historical trend toward the reduction of these parasites in the state of São Paulo attributable to improvements in these services ${ }^{14,27}$.

The exposure to intestinal pathogens of children studied at this daycare center does not seem to contribute to the occurrence of diarrhea or other intestinal symptoms. However, these results raise the question as to the real reasons that children in this daycare center manifested diarrhea. In fact, previous work on the etiological agents associated with diarrhea indicate that the relative importance of the various enteropathogens varies greatly depending on the season of the year, area of residence (urban or rural), socioeconomic class, geographical location and in particular, the age of the host ${ }^{42}$. Associated with this situation, diarrhea may be related to other non-infectious diseases or even by other enteropathogen infections, not investigated in this study. On the other hand, given the fact that many infants were asymptomatic carriers, it should be pointed out that this can be due to immunological tolerance mechanisms or intraspecific variations of bacterial communities that comprise the virulence of the parasite ${ }^{5}$. Thus, the present study provides a warning to authorities responsible for community healthcare concerning asymptomatic children, which can potentially pose a risk for outbreaks of gastroenteritis.

Finally, further investigations should be planned in the city of São José do Rio Preto and others within the diverse regions of the country, in order to increase knowledge and provide appropriate responses to these clinical infections with the elaboration of effective measures to prevent and control enteropathogens as a public health policy in Brazil.

\section{RESUMO}

Enteropatógenos detectados em crianças de creche no Sudeste do Brasil: pesquisa de bactérias, vírus e parasitos

Introdução: $\mathrm{O}$ objetivo deste estudo foi determinar a prevalência e o perfil etiológico de enteropatógenos em crianças de uma creche. Métodos: No período de outubro de 2010 a fevereiro de 2011 foram coletadas e analisadas amostras de fezes de 100 crianças matriculadas em creche do governo no município de São José do Rio Preto, Estado de São Paulo. Resultados: Um total de 246 bactérias foram isoladas em $99 \%$ das amostras de fezes; 129 eram diarreicas e 117 não-diarreicas. Foram isoladas setenta e três cepas de Escherichia coli, 19 de Enterobacter, uma de Alcaligenes e uma de Proteus. Foram detectados 14 casos de colonização mista com Enterobacter e de E. coli. Norovírus e Astrovirus foram detectados em crianças com sinais clínicos sugestivos de diarréia. Estes vírus foram detectados exclusivamente entre as crianças residentes em áreas urbanas. Todas as amostras fecais foram negativas para a presença das espécies de rotavírus A e C. Foi observada a presença de Giardia lamblia, Entamoeba coli, Endolimax nana e ancilostomídeos. Foi encontrada associação significativa entre o consumo de alimentos fora do centro da casa e creche e a presença de parasitos intestinais. Conclusões: Para as crianças desta creche, a infecção intestinal por patógenos não parece ter contribuido para a ocorrência de diarreia ou outros sintomas intestinais. As diferenças 
CASTRO, E.D.R.; GERMINI, M.C.B.Y.; MASCARENHAS, J.D.P.; GABBAY, Y.B.; LIMA, I.C.G.; LOBO, P.S.; FRAGA, V.D.; CONCEIÇÃO, L.M.; MACHADO, R.L.D. \& ROSSIT, A.R.B. - Enteropathogens detected in a daycare center, Southeastern Brazil: bacteria, virus, and parasite research. Rev. Inst. Med. Trop. Sao Paulo, 57(1): 27-32, 2015.

observadas podem ser atribuídas à grande diversidade de características geográficas, sociais e econômicas e o clima do Brasil, as quais tem sido relatadas como fatores críticos para a modulação da frequência de diferentes enteropatógenos

\section{ACKNOWLEDGEMENTS}

To all individuals enrolled in this study. The authors thank the Research Center of Microorganisms/FAMERP, state of São Paulo and Instituto Evandro Chagas - Section of Virology, MS/SVS, Ananindeua, state of Pará, for the partnership in carrying out bacteriological, parasitological, and viral analyzes.

\section{REFERENCES}

1. Adam RD. Biology of Giardia lamblia. Clin Microbiol Rev. 2001;14:447-75.

2. Almeida MTG, Silva RM, Donaire LM, Moreira LE, Martinez MB. Enteropatógenos associados com diarréia aguda em crianças. J Pediatr (Rio J). 1998;74:291-8.

3. Bencke A, Artuso GL, Reis RS, Barbieri NL, Rott MB. Enteroparasitoses em escolares residentes na periferia de Porto Alegre, RS, Brasil. Rev Patol Trop. 2006;35:31-6.

4. Boom R, Sol CJA, Salimans MMM, Jansen CL, Werthein-van Dillen PM, van der Noordaa J. Rapid and simple method for purification of nucleic acids. J Clin Microbiol. 1990;28:495-503.

5. Brink AK, Mahé C, Watera C, Lugada E, Gilks C, Whitworth J, et al. Diarrhea, CD4 counts and enteric infections in a community based cohort of HIV-infected adults in Uganda. J Infect. 2002;45:99-106.

6. Cardoso D, Fiaccadori FS, Souza MBLD, Martins RMB, Leite JPG. Detection and genotyping of astroviruses from children with acute gastroenteritis from Goiania, Goias, Brazil. Med Sci Monit. 2002;8:CR624-8.

7. Cardoso GS, Santana ADC, Aguiar CP. Frequência e aspectos epidemiológicos da giardíase em creches do município de Aracaju, SE, Brasil. Rev Soc Bras Med Trop. 1995;28:25-31

8. Carvalho TB, Carvalho LR, Mascarini LM. Occurrence of enteroparasites in day care centers in Botucatu (São Paulo State, Brazil) with emphasis on Cryptosporidium sp., Giardia duodenalis and Enterobius vermicularis. Rev Inst Med Trop Sao Paulo. 2006;48:269-73

9. Chikhi- Brachet R, Bon F, Toubiana L, Pothier P, Nicolas JC, Flahault $\mathrm{A}$, et al. Virus diversity in a winter epidemic of acute diarrhea in France. J Clin Microbiol. 2002;40:4266-72.

10. Cunliffe NA, Dove W, Gondwe JS, Thindwa BD, Greensill J, Holmes JL, et al. Detection and characterisation of human astroviruses in children with acute gastroenteritis in Blantyre, Malawi. J Med Virol. 2002;67:563-6.

11. Dalton RM, Roman ER, Negredo AA, Wilhelmi ID, Glass RI, Sànchez-Fauquier A Astrovirus acute gastroenteritis among children in Madrid, Spain. Pediatr Infect Dis J. 2002;21:1038-41.

12. Fagundes-Neto U. Gastroenterologia pediátrica e nutrição: diarréia persistente: uma guerra, cujo campo de batalha é o lúmem intestinal. 2010. Available from: http:/ gastropedinutri.blogspot.com/2010/12/diarreia-persistente-uma-guerra- cujo_21.html

13. Faust EC, Sawitz W, Tobic J, Odem V, Peres C. Comparative efficiency of various techniques for the diagnosis of protozoa and helminthes in feces. J Parasitol. 1939; $25: 241-62$.
14. Ferreira MU, Ferreira CS, Monteiro CA. Tendência secular das parasitoses intestinais na infância na cidade de São Paulo (1984-1996). Rev Saude Publica. 2000;34(6 Suppl):73-82.

15. Gabbay YB, Borges AA, Oliveira DS, Linhares AC, Mascarenhas JDP, Barardi CRM, et al. Evidence for zoonotic transmission of group $\mathrm{C}$ rotaviruses among children in Belém, Brazil. J Med Virol. 2008;80:1666-74.

16. Gabbay YB, Luz CRNE, Costa IV, Cavalcante-Pepino EL, Sousa MS, Oliveira KK, et al. Prevalence and genetic diversity of astroviruses in children with and without diarrhea in São Luís, Maranhão, Brazil. Mem Inst Oswaldo Cruz. 2005;100:709-14.

17. Gabbay YB, Jiang B, Oliveira CS, Mascarenhas JDP, Leite JPG, Glass RI, et al. An outbreak of group $\mathrm{C}$ rotavirus gastroenteritis among children attending a day-care center in Belem. Brazil. J Diarrhoeal Dis Res. 1999;17:69-74.

18. Gallimore CI, Barreiros MAB, Brown DWG, Nascimento JP, Leite JPG. Noroviruses associated with acute gastroenteritis in a children's day care facility in Rio de Janeiro, Brazil. Braz J Med Biol Res. 2004;37:321-6.

19. Giraldi N, Vidotto O, Navarro IT, Garcia JL. Enteroparasites prevalence among daycare and elementary school children of municipal schools, Rolândia, PR, Brazil. Rev Soc Bras Med Trop. 2001;34:385-7.

20. Gonçalves ACM, Gabbay YB, Mascarenhas JD, Yassaka MB, Moran LC, Fraga VD et al. Calicivirus and Giardia lamblia are associated with diarrhea in human immunodeficiency virus-seropositive patients from southeast Brazil. Am J Trop Med Hyg. 2009;81:463-6.

21. Gouvea V, Allen JR, Glass RI, Fang ZY, Bremont M, Cohen J, et al. Detection of group B and C rotaviruses by polymerase chain reaction. J Clin Microbiol. 1991;29:51923 .

22. Guimarães S, Sogayar MI. Occurrence of Giardia lamblia in children of municipal daycare centers from Botucatu, São Paulo State, Brazil. Rev Inst Med Trop Sao Paulo. 1995;37:501-6.

23. Gurgel RQ, Cardoso G de S, Silva AM, Santos LN, Oliveira RC. Creche: ambiente expositor ou protetor nas infestações por parasitas intestinais em Aracaju, SE. Rev Soc Bras Med Trop. 2005;38:267-9.

24. Hooffman WA, Pons JA, Janer JL. Sedimentation concentration method in schistosomiasis mansoni. P R J Public Health. 1934;9:283-98.

25. Kazuya M, Fujii R, Hamano M, Nakamura J, Yamada M, Nii S, et al. Molecular analysis of outer capsid glycoprotein (VP7) genes from two isolates of human group C rotavirus with different genome eletropherotypes. J Clin Microbiol.1996;34:3185-9.

26. Luchs A, Morillo SG, de Oliveira CM, Timenetsky M do C. Monitoring of group C rotavirus in children with acute gastroenteritis in Brazil: an emergent epidemiological issue after rotavirus vaccine? J Med Virol. 2011;83:1631-6. doi:10.1002/jmv.22140.

27. Ludwig KM, Frei F, Alvares Filho F, Ribeiro-Paes JT. Correlação entre condições de saneamento básico e parasitose na população de Assis, Estado de São Paulo. Rev Soc Bras Med Trop. 1999;32:697-704.

28. Mandomando IM, Macete EV, Ruiz J, Sanz S, Abacassamo F, Vallès X, et al. Etiology of diarrhea in children younger than 5 years of age admitted in a rural hospital of southern Mozambique. Am J Trop Med Hyg. 2007;76:522-7.

29. Mascarini LM, Donalísio MR. Giardíase e criptosporidiose em crianças institucionalizadas em creches no Estado de São Paulo. Rev Soc Bras Med Trop. 2006;39:577-9.

30. Miller SA, Rosario CL, Rojas E, Scorza JV. Intestinal parasitic infection and associated symptoms in children attending day care centres in Trujillo, Venezuela. Trop Med Int Health. 2003:8:342-7. 
CASTRO, E.D.R.; GERMINI, M.C.B.Y.; MASCARENHAS, J.D.P.; GABBAY, Y.B.; LIMA, I.C.G.; LOBO, P.S.; FRAGA, V.D.; CONCEIÇÃO, L.M.; MACHADO, R.L.D. \& ROSSIT, A.R.B - Enteropathogens detected in a daycare center, Southeastern Brazil: bacteria, virus, and parasite research. Rev. Inst. Med. Trop. Sao Paulo, 57(1): 27-32, 2015.

31. Moreira TF, Sampaio EM, Noronha MCC, Maia MJC, Freitas CEJ, Riedel OD. Nematelmintos detectados em amostras de fezes provindas de pacientes do Hospital Universitário de Fortaleza, Ceará, Brasil. Rev Bras Anal Clin. 1987;19:64

32. Mukherjee AK, Chowdhury P, Bhattacharya MK, Ghosh M, Rajendran K, Ganguly S. Hospital-based surveillance of enteric parasites in Kolkata. BMC Res Notes. 2009;2:110.

33. Nilsson M, Svenungsson B, Hedlund KO, Uhnoo I, Lagergren A, Akre T, et al. Incidence and genetic diversity of group $\mathrm{C}$ rotavirus among adults. J Infect Dis. 2000;182:678-84.

34. Noel JS, Lee TW, Kurtz JB, Glass RI, Monroe SS. Typing of human astroviruses from clinical isolates by enzyme immunoassay and nucleotide sequencing. J Clin Microbiol. 1995;33:797-801

35. Osterholm MT, Reves RR, Murph JR, Pickering LK. Infectious diseases and child day care. Pediatr Infect Dis J. 1992;11(8 Suppl):S31-41.

36. Parachar UD, Monroe SS. "Norwalk- like viruses" as a cause of foodborne disease outbreaks. Rev Med Virol. 2001;11:243-52.

37. Pereira HG, Azeredo RS, Leite JPG, Candeias JAN, Rácz ML, Linhares AC, et al. Electrophoretic study of the genome of human rotaviruses from Rio de Janeiro, São Paulo and Pará, Brazil. J Hyg (Lond). 1983;90:117-25.
38. Rockx B, De Wit M, Vennema H, Vinjé J, De Bruin E, Van Duynhoven Y, et al. Natural history of human Calicivirus infection: a prospective cohort study. Clin Infect Dis. 2002;35:246-53.

39. Rossit AR, Almeida MT, Nogueira CA, Costa Oliveira JG, Barbosa DM, Moscardin $\mathrm{AC}$, et al. Bacterial, yeast, parasitic, and viral enteropathogens in HIV- infected children from São Paulo State, Southeastern Brazil. Diagn Microbiol Infect Dis. 2007;57:59-66.

40. Schaub SA, Oshiro RK. Public health concerns about caliciviruses as waterborne contaminants. J Infect Dis. 2000;181(Supp12):S374-80.

41. Schnack FJ, Fontana LM, Barbosa PR, Silva LS, Baillargeon CMM, Barichello T, et al. Enteropatógenos associados com diarréia infantil ( $<5$ anos de idade) em amostra da população da área metropolitana de Criciúma, Santa Catarina, Brasil. Cad Saude Publica. 2003;19:1205-8.

42. Silva AM, Leite EG, Assis RM, Majerowicz S, Leite JP. An outbreak of g astroenteritis associated with astrovirus serotype 1 in a day care center, in Rio de Janeiro, Brazil. Mem Inst Oswaldo Cruz. 2001;96:1069-73.

Received: 9 January 2014

Accepted: 13 May 2014 